\title{
THE COMMUNITY AND THE CORPORATE AREA
}

Albert J. Reiss, Jr. $\dagger$

The purpose of this paper is to define the metropolitan community, to present something of what is known about its operational delimitation and to offer a discussion of problems in making corporate areas congruent with the territorial community. The paper is divided into three parts to accomplish these objectives. The first section distinguishes among the concepts of community, corporate area and region. The second section focuses on the census unit of the Standard Metropolitan Area after drawing a number of inferences from studies which use single or multiple-factor criteria to define operationally a metropolitan community. A concluding section points up certain implications of the discussion for devising corporate areas.

The terms "city," "metropolitan community" and "metropolitan region" often are used interchangeably. There are, for example, references to the Chicago metropolitan community which refer only to corporate Chicago city, and there are others to the Chicago region which, under the definitions of this paper, refer to the Chicago metropolitan community. The first problem, then, is to provide working definitions of the community, the corporate area and the region.

Hawley's working definition of a community is accepted for this paper. The community is ". . . that area, the resident population of which is interrelated and integrated with reference to its daily requirements, whether contacts be direct or indirect." 1

The basic distinguishing characteristic in this definition is that the community exists by organizing interdependencies-by integrating people and their institutions in a common daily life. Interdependence develops with the specialization of human activity. These specialized activities stand in such a complementary relationship to one another that they can be territorially integrated.

$\dagger$ Chairman, Department of Sociology and Anthropology, Vanderbilt University. Ph.B., 1943, Marquette University; M.A., 1948, Ph.D., 1949, University of Chicago. (1950).

1. Hawley, Human Ecology: A Theory of Community Structure 257-58 
The community arises by organizing and integrating interdependencies through a common center. ${ }^{2}$ When the common center is the focal point of integration for an area greater than that of its resident population, it is called a center of dominance. The common center always is relatively visible, although it may be a multi-nucleated center rather than a single nucleus.

The urban community is a dependent community since it maintains itself through exchange with other communities. The exchange occurs as the result of specialization in one or more functions and leads to intercommunity relationships. ${ }^{3}$ The structure of the dependent community is made up by integrating a diversity of functions, including such functions as production, trade, transportation and communication, and professional and business services.

The small urban community is composed largely of a primary area, the area of direct, though not necessarily personal, contact and communication among persons. The population in the primary area is integrated around a common center for the satisfaction of a major part of its daily requirements. There is considerable daily movement of a large segment of the population to and from this center. Large urban centers also have a secondary area which is chiefly an area of indirect contact and communication among persons and the institutions they represent. This pattern of contact and movement occurs with less frequency than in the primary area, though much of it is at least weekly. Many metropolitan areas also have a tertiary community area. Here contact also is indirect, but it is less frequent than in the secondary area, and influence is spatially discontinuous from the center of dominance. The export territory of a community often defines the tertiary area. Some cities perform national or world-wide functions so that they have very extensive tertiary areas. ${ }^{4}$ Modern technological means of transportation and communication have greatly enlarged the area of indirect contact for every community in an urbanized society, since these means make possible an increased number and diversity of interpersonal contacts without physical contact among the participants. The modern community center therefore can integrate the functions of a population dispersed over a much wider geographic territory than was previously the case.

The territorial integration of functionally differentiated units, while giving rise to a common center, also results in an indefinite

2. Id. at 238 .

3. Id. at 225 .

4. Hawley distinguishes among primary, secondary and tertiary areas of modern urban communities. Id. at $255-57$. 
periphery or boundary to the community. ${ }^{5}$ The major reasons for the indefiniteness of the periphery are four. There is, first, the fact that the size of the community area varies with the functions integrated by the center of dominance. In a modern metropolis, the areas of the functions integrated are not coterminous. In San Francisco, for example, the trade, newspaper circulation, commuter, labor market and professional service areas do not share a common boundary. The community therefore lacks a definite boundary, since it exists through the integration of these and other functions of the population. There is, second, the fact that no empirically exact or definite boundary can exist even for a single function, since the boundary of the function for one community merges ambiguously with that of another community. Two or more centers of dominance frequently compete more or less "equally" to serve a population in an area. This is true, for example, of many centers of the northeastern belt from New Jersey to Connecticut. The boundaries of neighboring communities converge or overlap so that community boundaries more often are zones rather than lines in territorial space. ${ }^{6}$ The fact that communities grow at varying rates at the periphery is a third source of difficulty in determining a boundary. Community growth or decline makes it difficult, even at a fixed point in time, to locate a zone at the periphery, since the zone is more or less in a state of flux. The community which remains relatively stationary in growth for a fairly long period of time provides an easier problem for boundary determination than does the expanding or declining one. The mobility of the population and its institutions presents a fourth source of difficulty in boundary determination. Population shifts, communication and transport networks, and other forms of exchange are vehicles for this mobility. The personnel and institutions of vice and crime, for example, generally are quite fluid in their location. Similarly, administrative functions, such as those found in governmental bureaus and military establishments, may shift their location and hence alter the functional integration of a community. The modern American metropolis, among the forms of historical community, presents problems of boundary determination in a most exaggerated form. The large metropolitan community in the United States characteristically

5. Cf. Comarunity Life and Soctal Policy: Selected Papers by Louis Wirth 161-62 (Marvick \& Reiss eds. 1956) ; HAwLEY, op. cit. supra note 1, at 245-46.

6. See Community Life and Soctal Policy: Seincted Papers by Louis Wirth 306 (Marvick \& Reiss eds. 1956). Wirth distinguishes two types of what he called metropolitan "regions" on the basis of the degree of definiteness of the periphery. In the first type, there are no clear competing centers with the metropolis, so that the boundaries fade into a no-man's land. In the second, there are competing centers and the boundary theoretically is said to occur at that point where the relative pull of the two centers is equal. 
is a multi-nucleated settlement integrating a host of functions; it is located in close competition with other, and lesser, centers, and evidences considerable growth and mobility in its population and institutions.

The corporate area is an area created to develop and/or apply a policy or law, carry on a public service, or enforce or adjudicate laws. ${ }^{7}$ Corporate areas for metropolitan communities in the United States are varied and numerous. The Standard Metropolitan Area (SMA) of Philadelphia, Pennsylvania may serve as an example. In 1950, the Philadelphia SMA had 2,071,605 inhabitants, who were governed in part by 702 local governments, or one local government for every 2,951 inhabitants. These 702 local government units included 333 school districts, 7 county governments, 199 township units, 140 municipal units and 23 special districts. ${ }^{8}$ The special districts include such administrative units as the Philadelphia Housing Authority and the Delaware River Port Authority. ${ }^{\circ}$

There are several distinctive attributes of the corporate area. First, the area itself is a matter of more or less arbitrary determination by legal means. The corporate government and/or administrative units which are spatially circumscribed within the metropolitan community generally grew up in an atmosphere of legislative strife, and of political conflict and compromise. The corporate units, therefore, in many cases are not the products of purely rational community considerations, but rather the consequence of socially conscious necessity and expediency. It need hardly be mentioned that expediential decisions often are "sound" by organizational criteria other than those of community, or that the highly fluid and changing conditions of the American metropolitan setting often make an area appear to be more arbitrary in its origin than it was. Usually, to be sure, some attempt is made to shape the corporate governing or administrative unit to an existing functional area or population, although the vision of the future often appears limited and the approximation very gross. ${ }^{\mathbf{1 0}}$

7. The term corporate area is used here as a term to cover all territorial units which derive from government, whether legislative, administrative or judicial. Some ecologists refer to the administrative area in similar terms, while others limit that term solely to an area which applies a policy or maintains a service. The more generic concept is preferred in this paper.

8. The data for Philadelphia are taken from U.S. BUREAU of THE CENSUS, DEP'T of Comlmerce, State and Local Governament Special Studies No. 36, Local GovERNMENT IN METROPOlitan AReas table 2 (1954).

9. Id. table 3 .

10. See, for example, Wirth's discussion of the historical bases of corporate units in his essay Localism, Regionalism and Centralization, reprinted in CommunrTy LIFE

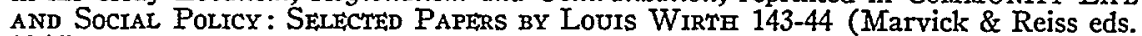
1956). 
A second major characteristic of the corporate area is the inflexibility of the boundary, once established. The formation of a corporate unit reinforces local identifications, creates vested interests, and so influences the location of facilities that it becomes difficult to change its territorial scope and powers, particularly to decrease them or to consolidate with larger units. This resistance is particularly marked in corporate units with taxing and zoning powers, but it occurs for the most part in every corporate unit. To these forms of resistance must be added another, the fact that constitutions and enacted law generally set quite rigid criteria and procedures for changing the scope of a corporate area, thereby limiting "competition" among areas. Moreover, the localistic ideology acts as a barrier to rational amelioration of "jurisdictional disputes" between large and small corporate units. The growth of a metropolitan community inevitably creates jurisdictional problems, with competition developing among formerly distinct units. The American local government and community growth patterns together create these jurisdictional problems, and our ideology makes their adjustment problematical.

The corporate area furthermore is created with a predetermined number of specific powers and functions. The practice most often followed in the case of administrative units is to set the corporate boundaries on an ad hoc basis. Thus, there are special areas for schools, for parks, for welfare and other functions as they become recognized in an historical context. No community ever approaches its government problem in toto, for it never exists that way historically. Reorganizations, consequently, are only temporary in a dynamic society. The territorial scope of a community shifts as its functional interdependencies change. But, a change in its corporate existence can occur only when there is public recognition of the problem and the necessity for change, and the willingness to use public means to bring about the change. Corporate changes necessarily lag behind functional changes in the community. The lag in time, of course, can be reduced with valid predictions of community change, and planning procedures based on them.

There is a fourth attribute of the corporate area which does not inhere altogether in its nature, but follows largely as a consequence of its historical development in American society. The community invariably expands into a territory where there are a diversity of corporate claims in relation to its functions. There is no historic, legal or cultural pattern for creating corporate units relating to the community which avoids complex jurisdictional problems as the 
community develops. The interdependencies which make up the community necessarily are not the sole, or in many cases even the primary, bases of the legal corporation or its administrative area. A particular function of a metropolitan community, for example, may fall within the purview of international, federal, state and a diversity of local jurisdictions. This may be true of such phenomena as the use of waterways through metropolitan communities, smoke or stream pollution, highway development, electric power development, recreation and the control of vice and crime, to name but a few examples. Compromise corporate areas have been created in some metropolitan areas to deal with these problems. The port authorities, sanitary districts and municipal housing authorities are examples of such compromise corporate areas. But such compromise solutions not only stand in the way of either monolithic or federated solutions to community government, they also indicate the jurisdictional complexity of a resolution. tion.

There is considerable documentation of the disjuncture between the metropolitan community and the corporate areas which serve it in part. A few examples may help to describe the nature and magnitude of the problem. The examples chosen are of overlapping jurisdictions. Overlapping, of course, does not preclude cooperative arrangements between two or more jurisdictions.

Assume that the Standard Metropolitan Area (SMA) is a reasonable approximation to the primary area of a metropolitan community. The number of local government units averaged ninety-six in the 168 metropolitan areas of the United States in 1950. Usually American metropolitan communities contain one or more size-groups of municipalities or towns, one or more counties and a diversity of special districts. Table 1 presents a summary of the local governing units for the 168 Standard Metropolitan Areas classified by the size of the largest central city in each area. The most striking relationship in the table is that, contrary to logical expectation, as the size of the largest central city increases, the number of local government units for every 10,000 inhabitants of the metropolitan area decreases. The smallest central cities have a ratio of about four local government units for every 10,000 inhabitants while the largest ones have a ratio of roughly one unit. This difference between the extreme size-groups is observed for each of the five types of local governments considered in table 1 , although the progression is not altogether orderly by size-class. The fact that there is considerable variation within any size-class is further evidence of the discontinuity between community and corporate areas. Among the four metropolitan areas of approximately the same 
Table 1.-Number of Local Governments Per 10,000 Intabitants of Standard Metropolitan Areas by Type of Governament, by Size of Largest Central City in Each Standard Metropolitan Area: 1952

\begin{tabular}{|c|c|c|c|c|c|c|c|c|}
\hline \multirow{2}{*}{$\begin{array}{l}\text { Size of } \\
\text { largest city in } \\
\text { each Standard } \\
\text { Metropolitan Area }\end{array}$} & \multirow{2}{*}{$\begin{array}{c}\text { Number } \\
\text { of } \\
\text { Standard } \\
\text { Metro- } \\
\text { politan ( } \\
\text { Areas }\end{array}$} & \multirow{2}{*}{$\begin{array}{l}1950 \\
\text { popu- } \\
\text { lation } \\
\text { (in thou- } \\
\text { sands) }\end{array}$} & \multicolumn{6}{|c|}{$\begin{array}{l}\text { Number of local governments per } 10,000 \\
\text { inhabitants of Standard Metropolitan Area }\end{array}$} \\
\hline & & & $\begin{array}{c}\text { All } \\
\text { local } \\
\text { govern- } \\
\text { ments }\end{array}$ & $\begin{array}{l}\text { School } \\
\text { dis- } \\
\text { tricts }\end{array}$ & $\begin{array}{l}\text { County } \\
\text { govern- } \\
\text { ments }\end{array}$ & $\begin{array}{l}\text { Town- } \\
\text { ships }\end{array}$ & $\begin{array}{c}\text { Munic- } \\
\text { ipal- } \\
\text { ities }\end{array}$ & $\begin{array}{l}\text { Non- } \\
\text { school } \\
\text { special } \\
\text { districts }\end{array}$ \\
\hline Total number ..... & 168 & $\longrightarrow$ & 16,210 & 7,864 & 256 & 2,328 & 3,164 & 2,598 \\
\hline All areas $\ldots . . \ldots \ldots$ & - & 84,671 & 1.9 & 0.9 & 0.03 & 0.3 & 0.4 & 0.4 \\
\hline $1,000,000$ or more .. & 5 & 29,463 & 1.2 & 0.5 & 0.01 & 0.2 & 0.3 & 0.2 \\
\hline 500,000 to $1,000,000$ & 13 & 18,246 & 1.4 & 0.6 & 0.02 & 0.2 & 0.4 & 0.2 \\
\hline 250,000 to $500,000 \ldots$ & 18 & 9,854 & 1.8 & 0.9 & 0.03 & 0.1 & 0.4 & 0.4 \\
\hline 100,000 to $250,000 \ldots$ & 55 & 15,487 & 2.3 & 1.0 & 0.04 & 0.5 & 0.4 & 0.4 \\
\hline 50,000 to $100,000 \ldots$ & 77 & 11,621 & 4.1 & 2.3 & 0.08 & 0.6 & 0.7 & 0.5 \\
\hline
\end{tabular}

Source: Based on data in U.S. Bureau of the Census, Dep't of Conarerce, State and Local Government Spectal Studies No. 36, Local Governatent in Metropolitan AREAS table 1 (1954).

size and with a central city of $1,000,000$ or more inhabitants, ${ }^{11}$ the range is from 960 local government units in Chicago to 298 local government units in Los Angeles. ${ }^{12}$

The disjuncture between the community and the corporate area similarly is suggested by the overlapping of the boundary zone of metropolitan communities in the United States with state and national boundaries. Table 2 lists the twenty-three, or 13.7 per cent, of the 168 Standard Metropolitan Areas in the United States in 1950 where the county units which make up the Standard Metropolitan Area were located in two or more state jurisdictions. The per cent of the metropolitan area population which resides on the opposite side of the state line from the central city varied in 1950 from 3.8 per cent of the Springfield-Holyoke, Massachusetts SMA population to fifty-two per cent of the Wheeling, West Virginia-Steubenville, Ohio population. There was surprisingly little difference in the percentage of the area population on the opposite side of the state line from the central city in 1950 as compared with 1940, except for Washington, D. C., where the territorial limitation of the district central city now obviously forces the bulk of the growth to occur outside of the district. For roughly one-half of the interstate Standard Metropolitan Areas, onefifth or more of the 1950 population was resident in a state adjacent to that in which the central city was located.

11. New York City is excluded from this size class because it is the primate city of the United States.

12. U.S. Bureau of the Census, op. cit. supra note 8 , table 2. 
Table 2.-Number of Inhabitants Resident in Standard Metropolitan Areas Which Cross State Boundary Lines, and Per Cent of Area Population on Opposite Side of State Line From Central City : 1950 and 1940

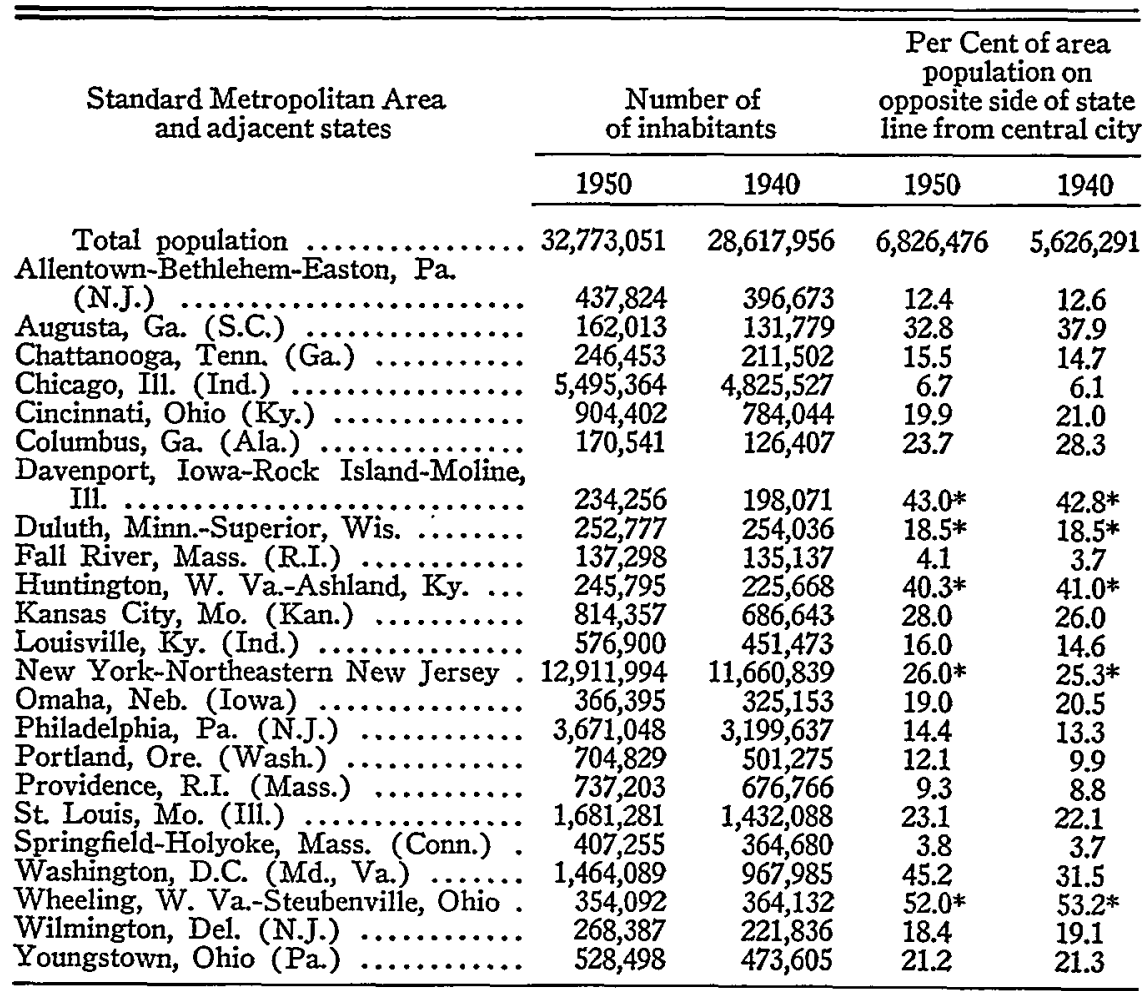

Source: 2 U.S. Bureau of the Census, Dep't of Commerce, 1950 Census of Population, Characteristics of the Population pt. 1, table 26.

* Since there is a central city on both sides of a state line, the city with the smaller population is tabulated on the "opposite side" of the state line.

To the twenty-three interstate metropolitan areas, one might add the three international metropolitan areas of Buffalo, New York, El Paso, Texas and Detroit, Michigan, the fourteen SMA's where the urban fringe lies in another state, ${ }^{13}$ and the ten SMA's which border closely on another state. ${ }^{14}$ A total of fifty, or 29.8 per cent

13. The names of these Standard Metropolitan Areas and the adjacent states are: Beaumont-Port Arthur, Texas (La.); Binghamton, N.Y. (Pa.); Charlotte, N.C. (S.C.) ; Evansville, Ind. (Ky.); Kenosha, Wis. (III.); Lawrence, Mass. (N.H.); Lowell, Mass. (N.H.); Memphis, Tenn. (Ark.); Mobile, Ala. (Miss.); St. Joseph, Mo. (Kan.) ; Sioux City, Iowa (Neb., S.D.) ; Sioux Falls, S.D. (Minn., Iowa); South Bend, Ind. (Mich.); Terre Haute, Ind. (III.).

14. The names of these Standard Metropolitan Areas and the adjacent states are: Albany-Schenectady-Troy, N.Y. (Mass.); Baltimore, Md. (Pa.); Erie, Pa. (N.Y., Ohio); Norfolk-Portsmouth, Va. (N.C.) ; Savannah, Ga. (S.C.); Shreveport, La. (Texas); Spokane, Wash. (Idaho); Toledo, Ohio (Mich.); Trenton, N.J. (Pa.); Wichita Falls, Texas (Okla.). 
of the 168 SMA's in 1950 thus bordered or crossed a state or national line. The combined 1950 United States population of the twenty-three SMA's which crossed a state line was $32,773,051$ inhabitants, while the United States population of the three areas which "crossed" a national boundary was $4,300,395$, and that of the twenty-four areas bordering closely on another state or "spilling" into it was 6,158,590. Or, 51.2 per cent of the total United States population resident in the 168 SMA's in 1950 was in or adjacent to an interstate metropolitan community. Roughly one in four persons in the United States thus lived in such an area in 1950.

There are a wide variety of problems arising from this split in state jurisdiction which necessarily complicates government and administration of the metropolitan area. They include such a diversity as the interstate bridge or tunnel (e.g., the Holland Tunnel between New York and New Jersey), smoke and stream pollution (e.g., the St. Louis and Kansas City smoke control programs and the Chicago Sanitary District), vice control (e.g., West Memphis, Arkansas, Phenix City, Alabama, and Calumet City, Illinois serve as vice centers for Memphis, Tennessee, Columbus, Georgia and Chicago, Illinois, respectively).$^{15}$

A region may be described as a spatially circumscribed conjunction of homogeneous physical, cultural and/or social factors which, taken together, set it apart from other and different conjunctions. The region will be more or less inclusive spatially, depending upon the degree to which the factors which set it apart from other regions are more or less inclusive. The region, then, is an area of homogeneous characteristics, and it will be more or less set apart from other regions to the degree that these are independent of the factors defining the other regions.

A socio-cultural region, like a community, has an indefinite periphery. The boundary of the region is quite fluid since culture contact at the periphery, and interregional population mobility and communication, affect the homogeneity of the cultural and social factors which set regions apart from one another. Socio-cultural factors also can alter to a degree the physical features of a region, at least so far as land use is concerned.

The region, unlike the community, characteristically lacks a center, since the region does not arise out of the integration of functions;

15. For a discussion of government problems in interstate metropolitan areas, see

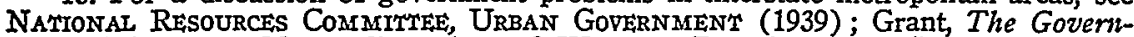
ment of Interstate Metropolitan Areas, 8 WESTERN POL. Q. 90 (1955); Haines, Metropolitan Area Regulation for Border-Line Cities, 41 PUB. UTI. FORT. 552 (1948). 
that is, it arises not through interdependence, but through likeness or homogeneity of function. Some "cultural regions" may recognize a "cultural center" which may be a capital city, a ruling or some other center. But, regions do not require centers as do communities.

Given this definition of a region, it is not logical to refer to metropolitan regions, although a network of cities or metropolitan communities, or some characteristic of them, might define a region. For instance, it may be useful to refer to world regions having varying patterns of urbanization. There is a theoretical problem here of the integration of cities or metropolitan communities in a system context. Metropolitan communities appear to be integrated into larger systems. There are economic export and import relations among them, and so on. This, in the opinion of the writer, must be treated as a separate problem. The integration of cities or metropolitan communities occurs in a large and inclusive system. By definition such a system would not be classified as a region, since it would be said to exist through interdependence, or differentiation and heterogeneity, rather than through the possession of homogeneous attributes. A special problem arises which is not easily dealt with in the theoretical context of a larger more inclusive system, however-the problem of the dominance of a community over other, and usually smaller communities. It is assumed, here, that dominance always defines the more inclusive community-hence there always is an overlapping of community structure. $^{16}$

It is difficult to satisfy empirically the criteria of regional definition, particularly if social and cultural factors are used in their definition. Data are not available to determine the degree of homogeneity of most socio-cultural characteristics in regional space, nor to assess the conjunction of factors in space so as to define the boundary of a region. Most socio-cultural regions, for example, are defined in a phenomenological sense with relatively arbitrary boundaries made to conform to physical or cultural features such as state lines. Data then are compiled for these areas to show differences among them.

An example of this practice is found in table 3. Mention has been made of the fact that regions may vary in their rate of urbanization. Table 3 shows the per cent distribution of the 1950 United States population by size of place for the four major census regions of the

16. Empirical studies of this dominance-subordinate relationship are found in Bogue, The Structure of THE METropolitan CoMmunity: A Study of Dominance and Subdominance (1949) and Vance \& Smith, Metropolitan Dominance and Integration, in The URBan SouTH 114 (Vance \& Demerath eds. 1954). The Vance and Smith article examines metropolitan dominance and integration of communities in the "southern region" of the United States. 
Table 3.-Per Cent Distribution of the Population by Size of Place, by Census Regions: 1950 *

\begin{tabular}{|c|c|c|c|c|c|}
\hline Size of place & $\begin{array}{l}\text { United } \\
\text { States }\end{array}$ & Northeast & $\begin{array}{l}\text { North } \\
\text { Central }\end{array}$ & South & West \\
\hline $\begin{array}{l}\text { Total } \ldots \ldots \ldots \ldots \ldots \ldots \ldots \\
\text { Urbanized areas: }\end{array}$ & 100.0 & 100.0 & 100.0 & 100.0 & 100.0 \\
\hline $3,000,000$ or more $\ldots \ldots \ldots \ldots \ldots$ & 14.0 & 31.2 & 11.1 & - & 20.3 \\
\hline $1,000,000$ to $3,000,000 \ldots \ldots \ldots$ & 11.1 & 17.0 & 12.3 & 5.2 & 10.6 \\
\hline 250,000 to $1,000,000 \ldots \ldots \ldots \ldots$ & 11.6 & 8.3 & 13.1 & 13.2 & 10.6 \\
\hline Under $250,000 \ldots \ldots \ldots \ldots \ldots$ & 9.3 & 10.0 & 8.5 & 9.8 & 8.3 \\
\hline Places outside urbanized areas: & & & & & \\
\hline 25,000 or more $\ldots \ldots \ldots \ldots \ldots \ldots$ & 4.7 & 3.2 & 5.6 & 5.0 & 5.2 \\
\hline 10,000 to $25,000 \ldots \ldots \ldots \ldots \ldots$ & 5.5 & 4.3 & 5.7 & 5.9 & 6.3 \\
\hline 2,500 to $10,000 \ldots \ldots \ldots \ldots \ldots$ & 7.9 & 5.6 & 7.8 & 9.6 & 8.6 \\
\hline 1,000 to $2,500 \ldots \ldots \ldots \ldots \ldots \ldots$ & 4.3 & 3.1 & 4.8 & 4.9 & 4.1 \\
\hline Under 1,000 (incorporated) .. & 2.7 & 0.9 & 4.7 & 2.6 & 1.9 \\
\hline Other rural: & & & & & \\
\hline Nonfarm .. & 13.9 & 12.0 & 10.0 & 18.9 & 14.6 \\
\hline Farm ....... & 15.0 & 4.4 & 16.4 & 24.9 & 9.5 \\
\hline
\end{tabular}

Source: 4 U.S. Bureau of the Census, Dep't of Commerce, 1950 Census of Population, Special Reports pt. 5, c. A, tables 1 and 6.

* This table is table 2 in Duncan \& Retss, Soctaz Characteristics of Urban and RuRat Comsrunities, 1950 (1956). It is reproduced here by permission of the Social Science Research Council and the Bureau of the Census.

United States. It is readily seen that there is considerable variation in the degree of urbanization of these four regions. The South has the lowest degree of urbanization while the Northeast has the highest. There is difficulty, however, in determining what these differences mean in regional terms, since these four regions differ widely as a result of many causes-geographic, historical, cultural and social. One is not sure what factors produced these differences in urbanization. Without knowing to what the differences are attributed one cannot determine whether urbanization is independent of region in this context. Furthermore, regions always are part of a larger system which theoretically is independent of other systems, while the region is not. Regional analysis always is confounded by this fact, since considerable "interaction" among regions is possible.

\section{II}

Operational delimitation of a metropolitan community is rendered difficult by a number of factors. (1) The nature, quantity and quality of the data available to measure functional interdependence are generally not such as to render definition easy and to allow quick and accurate measurement of changes in its size, form and composition.

17. See Spengler, Regional Differences and the Future of Mamufacturing in America, 7 So. J. EcoN. 475 (1941). 
Composition, for example, may change because new factors arise which hitherto were unaccounted for. (2) The choice of defining characteristics is not specified succinctly enough, either in theory or operations, so that one can simply gather data to measure the particular factors which are integrated in a center of dominance. One first has to determine which are the dominance characteristics to be measured. The spatial dimensions of the community vary with the functions selected as integrated by a particular center of dominance vis-à-vis integration by a competing center of dominance. Present theory implies that no precise spatial boundary ever is located for a metropolitan community, and that the boundary of a community becomes even less distinct the closer the centers are in geographic location and/or in functional competition.

The several factors which define a metropolitan community are not specified in theory, except to offer the rule that the community is that area where the resident population is interrelated and integrated with reference to its daily requirements or to say that the community is a spatially circumscribed functional integration of interdependent factors through a center of dominance. Students of the metropolitan community, however, have proposed a wide variety of indexes and factors to define operationally this area of functional interdependence. It is obvious that all indexes apply to a space which initially is identified by locating a densely settled area of population which is called the center of dominance, although this procedure need not be followed, for the plotting of "metropolitan" characteristics or their consequences on a grid leads to a similar identification. The second step in operationally defining the community is to isolate some functional characteristics which the center presumably integrates, these then being considered its dominance functions. The characteristics may be economic, such as retail trade dominance, socio-cultural, such as mass media dominance, or a specific criterion of contact, such as daily commutation. The criteria selected exert a profound influence in circumscribing the spatial area of the community. The retail trade area is much larger than the daily commutation area of American cities, for example. The third step is to measure empirically these characteristics in geographic space as one proceeds outward from the previously identified center of dominance. Ideally, a dominance characteristic is one which decreases in intensity as one moves outward from the community center, with the periphery reached at an "indifference point," or one where the relationship to distance reverses (often presumed to be the periphery of some other community). In empirical cases, as Bogue and others have shown, the influence of the larger community is direct only for a given 
distance when the relationship becomes indirect due to competition from smaller or subdominant places which successfully compete to a degree with the dominant. ${ }^{18}$

Research investigations show that the boundaries of a modern community are empirically indeterminate when several indexes are employed. Harris, for example, found considerable irregularity in the boundaries of Salt Lake City when he plotted indexes of retail trade, wholesale grocery trade, wholesale drug trade, newspaper circulation, radio broadcasting, telephone communication, extent of Mormon religious practice, petroleum distribution, bakery distribution, generalized trade and federal reserve bank deposits. The retail trade area gives the most circumscribed area in Harris' study, while the radio broadcasting, financial, telephone, wholesale drug and petroleum service areas extend farthest beyond Salt Lake City. ${ }^{19}$ In general, empirical studies of metropolitan communities show that indexes of direct contact or movement, e.g., of commutation and of daily distribution of local trade or services, e.g., milk delivery, define a comparatively small area - the primary community. Retail trade and certain professional and institutional services define a somewhat larger area, while those services or functions where distance is most easily overcome, or where competition from smaller centers is least likely, define the most inclusive area.

The failure of a multiple-criteria index to yield an unequivocal description of the metropolitan community has led some to propose single-criterion indexes to define a community operationally or empirically. Park and Newcomb suggested the circulation radius of newspapers published in a center as a single-criterion index on the postulate that newspapers represent a multiplicity of community interests. ${ }^{20}$ Others recommend commutation, or other indexes of daily contact, as a "best" single index. But a single index will not give an unequivocal definition of a boundary either, as the previously cited studies by Bogue and others have shown.

The choice of an index to measure the area of a community is a special problem requiring further developments in ecological theory and empirical investigation. At present, the guide to a choice of an index to define a community empirically rests principally on making a choice between criteria which define the primary community of direct contact and those which define a secondary area of indirect contact.

18. See Bogue, op. cit. supra note 16, at 117-18; Kish, Differentiation in Metropolitan Areas, 19 AM. Soc. REv. 388 (1954).

19. Harris, Salt LakE, City, A Regional Capital (1940).

20. Park \& Newcomb, Newspaper Circulation and Metropolitan Regions, in McKenzie, The Metropolitan Community 106 (1933). 
The operational definition of a metropolitan community most commonly in use today as a data collection unit is the Standard Metropolitan Area (SMA) adopted by federal agencies in the late 1940's. Prior to that time a number of definitions were used for the collection and analysis of federal statistics-the metropolitan district of the Census of Population, the labor market areas of the Bureau of Employment Security and the industrial areas of the Census of Manufacturers. The usefulness of data for any of these areas was restricted by the fact that they were not comparable to other sets of areas. A federal committee under the Bureau of the Budget, therefore, developed the Standard Metropolitan Area so that a wide variety of statistical data could be presented on a uniform basis. A Standard Metropolitan Area is a county or group of counties which contains at least one city of 50,000 inhabitants or more. Counties contiguous to the county with the central city of 50,000 inhabitants or more are included in an SMA if they are considered metropolitan in character and if they are judged to be socially and economically integrated with the central city.

The operational criteria of the metropolitan character of a contiguous county relate primarily to the county as a place of work or residence for nonagricultural workers; specifically:

"(1) The county must (a) contain 10,000 nonagricultural workers, or (b) contain 10 per cent of the nonagricultural workers working in the standard metropolitan area, or (c) have at least one-half of its population residing in minor civil divisions with a population density of 150 or more per square mile and contiguous to the central city.

"(2) Nonagricultural workers must contribute at least twothirds of the total number of employed persons of the county." 21

The extent of communication between the outlying counties and the central county is the major criterion of metropolitan integration. The specific operational criteria used are:

"(1) Fifteen per cent or more of the workers residing in the contiguous county work in the county containing the largest city in the standard metropolitan area, or

(2) Twenty-five per cent or more of the persons working in the contiguous county reside in the county containing the largest city in the standard metropolitan area, or

(3) The number of telephone calls per month to the county containing the largest city of the standard metropolitan area from

21. 2 U.S. Bureau OF THE CENSUS, Dep'T OF Commerce, 1950 Census of PopuLATroN (hereinafter cited as CENSUS: 1950), Characteristics of the Population pt. 1, at 27 . 
the contiguous county is four or more times the number of subscribers in the contiguous county." 22

In New England, the units used in defining SMA's are towns and cities rather than counties. A population-density criterion of 150 persons or more per square mile, or 100 persons or more per square mile where the integration criteria were met, was used.

The thickly settled core of the Standard Metropolitan Area, with a few exceptions, is defined as an urbanized area. This is primarily the area one sees as the physical city or the "built-up area." The largest legal city in an SMA is the principal central city, but any other city of 25,000 or more inhabitants within an SMA, and having a population amounting to one-third or more of the population of the central city, is also a central city, provided that no more than three cities have been defined as central cities. ${ }^{23}$

There were 168 Standard Metropolitan Areas in the continental United States in 1950. Their aggregate population in 1950 was $84,500,680$ or 56.1 per cent of the total population. ${ }^{24}$ Officially there were 172 SMA's in the United States in 1955. The 1681950 SMA's had an estimated 1955 population of $95,304,000$ or roughly fifty-nine per cent of the total population. ${ }^{25}$ The 1950 total SMA population was distributed such that 58.5 per cent lived in the corporate central cities. There were forty of the 168 SMA's, however, with less than half their total population in their central cities. Of the twelve SMA's with principal central cities in Pennsylvania, nine had more than half their population outside their central cities, and in California six out of eight are in this group. ${ }^{26}$

The variation in this ratio of the population within to that outside the central city is substantial among the SMA's. The Boston, Massachusetts SMA, for example, had only 33.8 per cent resident in Boston city, while the much larger Chicago, Illinois SMA had 65.9 per cent resident in Chicago central city. Some middle-sized metropolitan centers such as Memphis, Tennessee and Indianapolis, Indiana had as many as 82.1 per cent and 77.4 per cent, respectively, resident in the central city. ${ }^{27}$ The variation is even greater for the ratio within the central city to that in the urbanized area. The variation in these ratios

22. Id. at $27-28$.

23. Id. at 28 .

24. Ibid.

25. U.S. Bureau of The Census, Dep't of Commerce, Current Population REPORTS SER. P-20, No. 63, at 1 (1955).

26. 2 Census: 1950, Characteristics of the Population pt. 1, at 28.

27. These percentages are based on data in id. table 27 . 
serves as further documentation of the discontinuity between a primary community-the SMA or urbanized area-and a corporate area-the corporate central city.

The Standard Metropolitan Area is based on a single corporate unit, the county or the New England town, or in combinations of the whole unit. As such, it uses a criterion which in no case is inclusive of the extended or secondary metropolitan community where contact is essentially indirect, or for that matter the tertiary area either. On the other hand, in many instances the SMA appears to be a rough approximation to the primary community where contact is essentially direct. ${ }^{28}$ For some SMA's, the urbanized area extends beyond the county boundaries of the SMA, however. Furthermore, because the county unit varies so in size from state to state (e.g., they are unusually large in California and Texas), there is considerable variation in the inclusive territory. The SMA, then, is at best a compromise data-collection unit which varies considerably in its validity as an operational definition of the primary community.

III

The discussion to this point implies that the disjuncture between the community and corporate areas makes it difficult for a community to act on its problems. The community processes of government regulation, the provision of services and the derivation of its financial, legal and moral support in particular are disjunctive. The implications of this disunity for planning and corporate action are explored further in this section.

The lack of coincidence between corporate areas and the territorial scope of a community public and its problems is a major obstacle to the exercise of authority in formulating and carrying out public policy in relation to its problems. For many American metropolitan communities, jurisdictional authority is so restricted, or overlapping, that any single unit can make only a piecemeal approach to resolve the problem. Most communities, too, have few if any actual vehicles for cross-jurisdiction problem-solving. The major obstacle to community planning and problem-solving, then, lies in the presence of one or more of the following conditions, that no comprehensive corporate area coincides with the territorial community, that the scope of any single corporate area often does not coincide with the territorial scope of a

28. A recent study by Hawley observes: "The definition of the Standard Metropolitan Area is selective of the most rapidly growing parts of satellite areas. In other words that concept of metropolitan area encompasses the parts of outlying area that are most immediately responsive to developments in the central city." HAWLEY, THE Changing Shape of Metropolitan America 161 (1956). 
particular community problem or that no corporate devices exist to resolve cross-corporate problems.

A variety of corporate entities have been invented, proposed or adopted to deal with problems arising from the disjuncture between the territorial community and the corporate area. The major ones include the following: $(a)$ annexations of territory into which the community expands, annexation occuring either prior to or after the expansion; (b) consolidation of whole city and county units; (c) detachment of a city from the remainder of the county, known as citycounty separation; $(d)$ transfer or reallocation of functions or services from one or more local governments to another; $(e)$ cooperative handling of a function or service by two or more local governments; $(f)$ creation of special metropolitan districts to perform one or more functions or services; $(g)$ creation of a general metropolitan government for community-wide functions, with local governments retaining local functions, sometimes known as federation. ${ }^{29}$ Other corporate arrangements can be devised within our culture context, or for that matter, beyond it. Yet these arrangements and their potential efficacy must be viewed within the context of the community, and the culturecontext within which it, in turn, rests. The problem of devising and effecting corporate arrangements for community problems now is discussed in the context of the community and its cultural setting.

(1) The problem created by the disjuncture of community and corporate territories must be solved within the context of an American ideological controversy of localism versus centralization. ${ }^{30}$ Americans value local practices and authority, particularly in government, and fear centralization of authority. The traditional view of Thomas Jefferson against centralized authority and of state and local rights is a strong one. Merriam expresses one form of this American view: "In a national state, and especially in a democracy, it is of the highest importance that the necessary role of local self-government in matters that are really local be protected and preserved." 31 One must mention, however, that Americans are inclined to consider most matters more, rather than less, local, despite the fact that historically the reverse is the case as the area of local interdependence grows ever larger. The continued

29. For an extended discussion, appraisal and empirical instances of these corporate devices, see Council of STATE GovirRnaneNT, The STATES AND THE METropolitan Problear: A REPORT to THE GOVERNOR'S CoNFERENCE pts. 2 and 3 (1956).

30. See Localism, Regionalism and Centralization, in Communiry LIFE AND SoCIAL Policy: Selected Papers by Louis WirTh 143 (Marvick \& Reiss eds. 1956), for an excellent historical treatment of the localism-centralization value controversy in relation to metropolitan planning.

31. Merriam, Urbanism, in Eleven Twenmy-Six: A Decade of Socral Scrence RESEARCH 32 (1940). 
insistence on maintaining many small units of local government and administration and on continued creation of them, despite the inadequacies mentioned, seems to be a form of reaction against this growing interdependence, and an implicit recognition of it. The choice of corporate units congruent with the community and its problems then rests in this kind of value controversy: shall local autonomy be surrendered to extra-local determination? shall local values be sacrificed to centralized efficiency? will extra-local authority pay attention to purely local considerations? These and similar controversial questions generally arise in relation to changing or creating corporate boundaries. Any proposal for administrative reorganization of a metropolitan community must recognize the limitations imposed by this value context. Some of the proposed corporate communities are more compatible with the American predilection for local autonomy than are others. The federation arrangement in many ways seem to compromise local and extra-local values within the American culture context better than most other centralized arrangements. Yet it seldom has been seriously proposed for adoption in metropolitan areas of the United States, and never adopted, though Toronto, Canada, adopted a federation plan in 1953.

(2) Corporate areas, once created, become barriers to future change of corporate boundaries. The sentiment and symbolism, the vested interests and authority, attached to these corporate units become barriers to change. Communities may "cross" state boundaries or more local ones, and they have crossed not only a legal barrier, but a symbolic public one as well. There is a general recognition of these barriers when attempts are made to create new governmental units from old ones. What is not as clearly seen, however, is the fact that the new units similarly will become invested with a symbolic and institutional existence, so that changing them later also is difficult.

(3) The legal criteria and procedures established in American society to change corporate, including administrative area, boundaries for the most part are extremely rigid. Probably the most difficult ones to change are those where a metropolitan community crosses a national or state boundary, but despite variation among the states, procedures for changing the boundaries are relatively inflexible at all levels of local government. There are a number of historical reasons for this cultural fact which need not be developed here. Since the problem of multiple local units in many ways is the most pressing one confronting metropolitan communities, the question of the relative flexibility of procedure for changing these boundaries is particularly crucial. The more local 
the unit, of course, the more likely it is that change in the larger community will affect its composition. And, therefore, the more incongruent its boundaries may become.

This is not the point to explore the value questions of whether the legal criteria and procedures to change boundaries ought to be changed, or to explore the factual question of whether in a particular instance it is possible to change them. The fact of the matter is that if present corporate boundaries were made concurrent with community boundaries or problem areas, insofar as the nature of the case permits, it would appear that as the new community or problem area boundaries shift they would be as difficult to change as is presently the case. This at least suggests that one way to cope with the problem of the congruence of the territorial community with the corporate area is to make the legal procedures for changing boundaries less rigid. The criteria of consent, of intercorporate arrangement and of the creation of new units should be carefully examined in this context.

(4) The jurisdictional problem further is complicated by the fact that it may not be possible or practicable for the scope of a particular problem in the community to coincide with government and administrative units for the community, given the nature of the community, the corporate area and the problem, or of all three. This may be so for a number of reasons. The problem in fact may be common to a number of communities, so that the corporate area related to a single community is logically incapacitated for its solution. This holds for many problems such as public health, crime, unemployment, navigation and stream pollution. For these problems, or particular levels of them, the choice appears to be between a single centralized authority for the several communities and a special authority related only to this and other common problems. Existing metropolitan districts for the control of navigation, smoke abatement or other common problems are of this nature.

A second reason for the difficulties encountered in establishing boundaries is the fact that the growth of the community invariably extends it into the sphere of previously existing communities, gradually integrating much of its population and institutions, and its dominance attributes. Corporate boundaries, therefore, cannot be extended indefinitely in advance of anticipated community growth, since there are many local governments already located within the potential territory of the community.

Perhaps the limiting condition to setting corporate boundaries is the fact that the community boundary is a zone rather than a strict 
boundary; corporate boundaries are definite and, therefore, necessarily not coincident with the community zone. Mention may be made again at this point of the inherent arbitrariness of all corporate units at the local level. The territorial scope of a problem or function varies by the type of problem or function. This means that the territorial scope of several problems or functions does not result in a coincidence of boundaries for them. A single administrative area equally functional for all problems thus is a contradiction in terms. It likewise is difficult to see how any corporate unit for a metropolitan community can be made to conform to the actual scope of certain classes of problems such as population movement, crime and vice, recreation or the economic distress of its inhabitants. For a variety of reasons, it seldom is practicable accurately to adjust the boundaries of corporate areas to the scope of these phenomena, so that the scope of any corporate area as a practical consideration to some degree is arbitrary.

(5) The problem of making corporate areas congruent with the community is exacerbated further by the fact that certain activities purposely seek their location beyond the confines of corporate communities, or within communities of their own creation. This may be true for such diverse activities as a vice district, an exclusive residential area, and a modern factory or business. The rural-urban fringe, in fact, takes on a particular complexion of marginal land uses. ${ }^{32} \mathrm{~A}$ fact that must be dealt with, then, is the legal control of location-to control activities which locate specifically to escape corporate control or responsibilities. The resolution of this problem perhaps is most difficult for it rests in another matrix of values-freedom to move and to locate, and the "right" to create one's own local authority in selfinterest.

A few concluding remarks may be in order in the nature of an epilogue. The problem of creating or revising corporate areas in relation to the ecological community is a continuing one. Like all social problems, it never is entirely resolved. Its solution is apt to be particularly ephemeral in a highly dynamic society such as is American society. Corporate area boundaries necessarily only approximate the community problem area-given the phenomena with which one is dealing, changes in them, and the cultural context within which they are approached.

The foregoing observations and discussion have proceeded with an analytical distinction in part based on the community as a product of growth and the corporate area as a product of human endeavor.

32. Firey, Ecological Considerations in Planning for Rurban Fringes, 11 Am. Soc. REv. 411 (1946). 
This distinction should not lead to the conclusion that human endeavor does not shape the territorial scope of the community as well as that of the corporate area. For it does, but it does so much less directly. It is well to remember, nevertheless, that a study of the community as the result of more or less natural processes of growth (those least influenced by direct human intervention and predetermined design) is a prerequisite to a solution of the corporate problem in metropolitan communities. 